\title{
Downeshela oliveirai, a new neotropical predaceous midge from northern Brazil (Diptera, Ceratopogonidae)
}

\author{
Maria L. Felippe-Bauer \& Cristiane S. Silva
}

Laboratório de Diptera, Instituto Oswaldo Cruz-Fiocruz, Av. Brasil 4365, 21040-900 Manguinhos, Rio de Janeiro, RJ, Brazil. (mlfbauer@ioc.fiocruz.br; cssilva@ioc.fiocruz.br)

\begin{abstract}
A new species of Downeshelea Wirth \& Grogan, 1988, D. oliveirai, is described and illustrated based on male and female characteristics. The specimens were collected in Rondônia and Pará states, northern Brazil.
\end{abstract}

KEY WORDS. Downeshelea, Neotropical Region, Rondônia, Pará, new species.

RESUMO. Downeshela oliveirai, uma nova espécie neotropical de ceratopogonídeo predador para a região norte do Brasil. Uma nova espécie de Downeshelea Wirth \& Grogan, 1988, D. oliveirai, é descrita e ilustrada baseada nas características dos machos e fêmeas. Os espécimes foram coletados nos estados de Rondônia e Pará, região norte do Brasil.

PALAVRAS-CHAVE. Downeshelea, Região neotropical, Rondônia, Pará, espécie nova.

Wirth \& Grogan (1988) in their revision of the predaceous midges of the world placed the species of the Monohelea multilineata group in a new genus, Downeshelea, which includes 30 neotropical species. Borkent \& SPINELli (2000) listed 18 species south of the United States of America. Six of them were originally described from Brazil and only two, D. cebacoi (Lane \& Wirth, 1964) and D. guianae (Wirth, 1953), are reported from northern Brazil.

Material from light trap collections from Rondônia and Pará states included an undescribed species of Downeshelea that we describe herein.

The terminology used is that adopted by WIRTH \& Williams (1964) for North American species of Monohelea Kieffer, 1917, LANe \& WiRTh (1964) for Neotropical species, and RatanaWorabHan \& WirTH (1972) for Oriental species. The terms of wing veins follow the system of the Manual of Neartic Diptera (MAC AlPINE et al., 1981), with modifications proposed by SzADZIEWSKI (1996). All measurements are in micrometers, except those of the wings which are in millimeters.

\section{Downeshela oliveirai Felippe-Bauer, sp.nov. (Figs 1-15)}

Diagnosis. D. oliveirai has similar wing pattern and the same geographic distribution of $D$. guianae. It can be distinguished by its greater size (wing length 1.35 $\mathrm{mm} ; 1.10 \mathrm{~mm}$ in D. guianae) and peculiar aspect of parameres and aedeagus.

Female. Wing length 1.08-1.46 (1.35; n=9) mm; breadth $0.42-0.62(0.52 ; \mathrm{n}=8) \mathrm{mm}$.

Head. Brown. Eyes (Fig. 4) bare, narrowly contiguous in lower portion. Antenna (Fig. 3) brown except on basal portion of flagellomeres; flagellomeres cylindrical, with mean lengths of 59-40-42-43-43-48-4848-75-75-80-80-101 $\mu \mathrm{m}$ ( $\mathrm{n}=9$ ), Antennal Ratio (11-15/310) 1.08-1.17 (1.11; n=9). Palpus (Fig. 5) uniformly brown, longer than proboscis; lengths of segments 29-48-74-42$58 \mu \mathrm{m}$; $3^{\text {rd }}$ segment cylindrical, slightly swollen distally, with a moderately deep sensory pit in mid portion; Palpal Ratio 2.2-2.8 (2.6; $n=9)$. Mandible with 11 teeth.

Thorax. Brown, without definite pattern in slide mounted specimens. Legs (Fig. 8) brown, the hind slightly darker; knees yellowish; fore and hind tibiae with apical spur, longer in fore leg; hind tibial comb with six bristles; lengths of trochanters, femora and tibiae of fore, mid and hind legs 117-533-522, 117-640-608, 128-746-683 $\mu \mathrm{m}(\mathrm{n}=10)$. Tarsi (Fig. 7) pale, pilose; ventral palisade setae in one row on hind basitarsus; fore and hind basitarsi with one basal and one apical spine; mid basitarsus with 2 basal, 2 apical and 3-4 ventral spines; apical spines of tarsomeres 2-4 of fore, mid and hind legs as follows: 1-1-1, 2-2-1, 1-12 , basal spines absent; lengths of fore, mid and hind tarsomeres 245-117-74-53-106, 309-128-74-53-96, 458-192$117-85-85 \mu \mathrm{m}(\mathrm{n}=10)$; fore, mid and hind tarsal ratios 2.3, 2.4, $2.2(n=6)$; claws of fore and mid legs paired, equal sized, about 0.6 times as long as $5^{\text {th }}$ tarsomere; hind leg with a single claw, about 1.1 times as long as $5^{\text {th }}$ tarsomeres. Wing (Fig. 1) hyaline, scattered macrotrichia distally in cell $\mathrm{r}_{3}$ and $\mathrm{m}_{1}$, microtrichia absent; 2 conspicuous dark spots, one locate on the r-m crossvein reaching the medial fork, the other in cell $r_{3}$, extending from the end of $2^{\text {nd }}$ radial cell to vein M1; six inconspicuous grayish, diffuse areas in apical portions of cells $\mathrm{r}_{3}, \mathrm{~m}_{1}, \mathrm{~m}_{2}$ (this one reaching to vein M2 and extending from cell $\mathrm{m}_{1}$ ), cua $_{1}$ (this one reaching vein $\mathrm{CuA}_{1}$ ) and veins M1 and $\mathrm{CuA}_{2} ; 2^{\text {nd }}$ radial cell nearly twice as long as $1^{\text {st }}$; costal ratio $0.77-0.81(0.79, \mathrm{n}=9)$.

Abdomen. Brown. Two subspherical spermathecae (Fig. 6) slightly unequal, measuring 69 by $53 \mu \mathrm{m}$ and 57 by $45 \mu \mathrm{m}$; a vestigial $3^{\text {rd }}$ present, $16 \mu \mathrm{m}$ long.

Male. Wing length 1.13-1.32 (1.27, n=5) mm; breadth 0.40-0.46 $(0.43, n=5) \mathrm{mm}$. Similar to female with usual sexual differences; eyes as in figure 10; antenna (Fig. 9) with brown pedicel, flagellomeres 13-15 brown; 4-11 
somewhat barrel-shaped, 12 nearly twice as long as wide, 13-15 elongated, lengths of flagellomeres 122-42-42-4140-40-40-40-40-62-135-115-112 $\mu \mathrm{m}$; Antennal Ratio (12-15/ 3-11) 0.94-0.99 (0.95, $n=5)$; palpus as in figure 11. Lengths

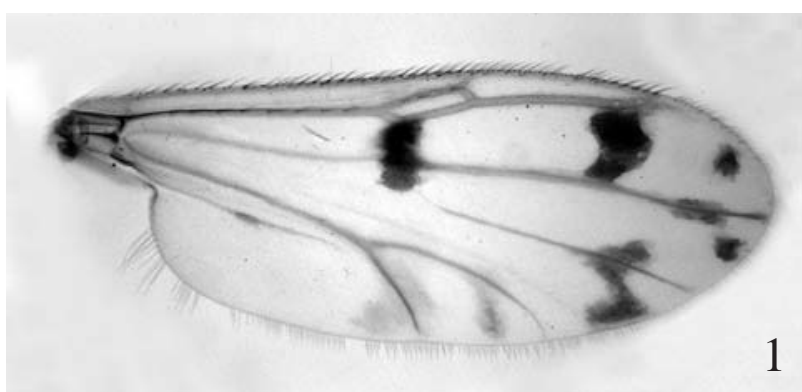

of trochanters, femora and tibiae of fore, mid and hind legs 117-501-480, 106-586-533, 117-650-586 $\mu \mathrm{m}$ (n=7) (Fig. 15). Tarsi (Fig. 12) pale, pilose; fore and hind basitarsus with one basal and one apical spine; mid basitarsus with

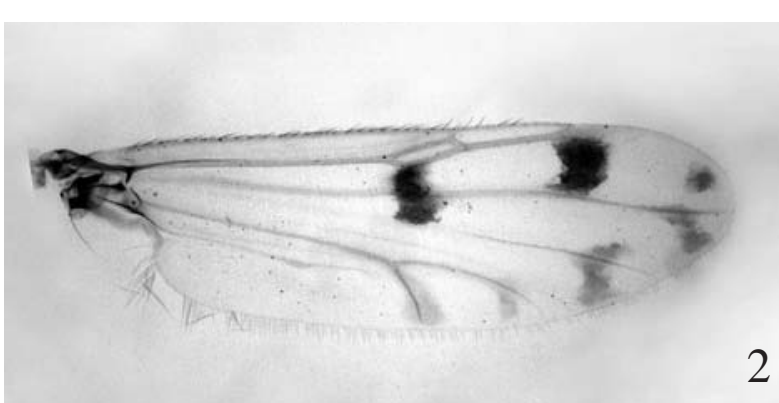

Figs.1-2. Wing photographs of Downeshelea oliveirai sp.nov.: 1, female; 2, male.

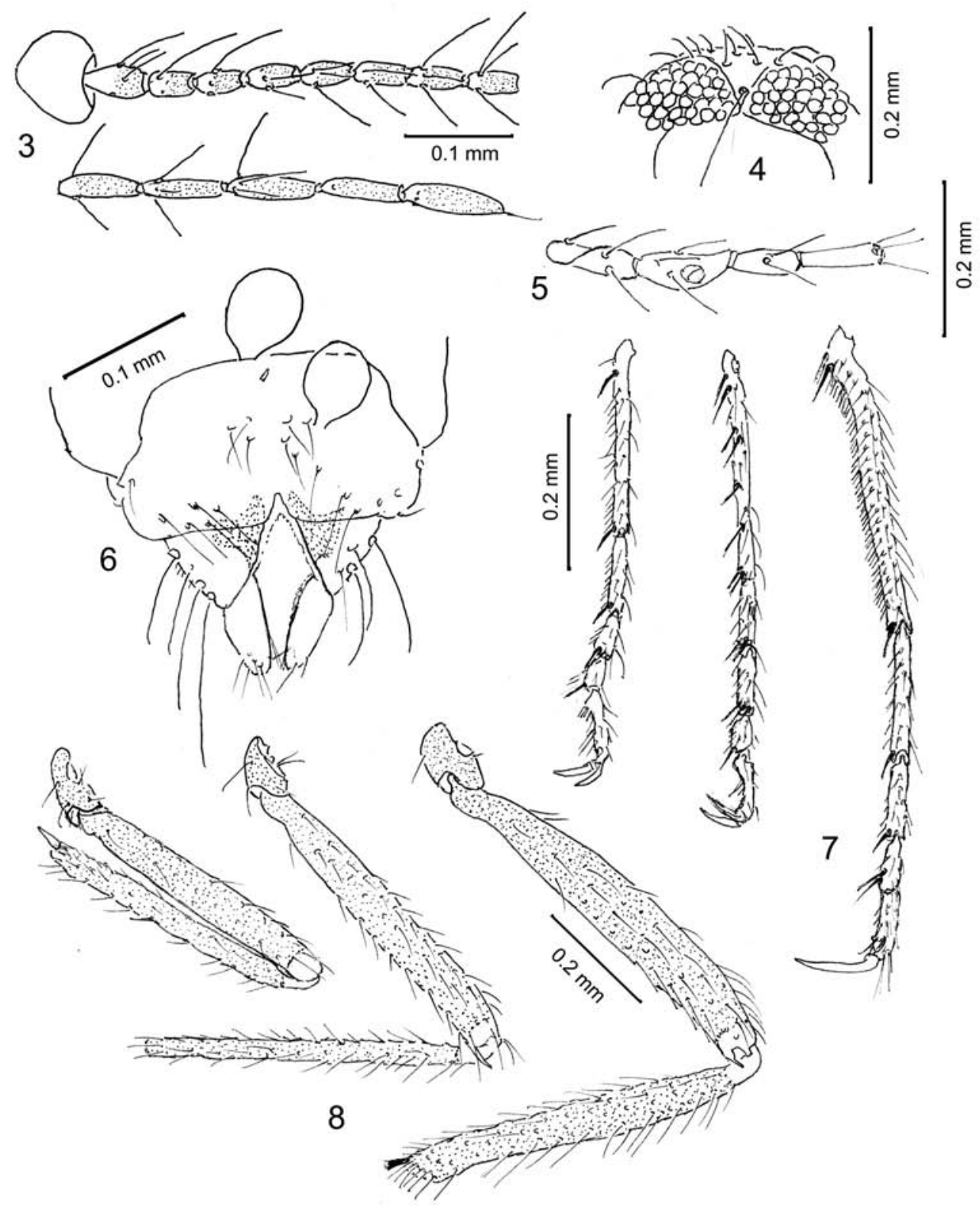

Figs. 3-8. Downeshelea oliveirai sp.nov., female: 3, antenna; 4, dorsal portion of head capsule, in anterior view; 5, palpus; 6, terminalia, showing spermathecae; 7 , tarsi (left to right) fore, mid and hind; 8, legs (left to right) fore, mid and hind. 
2 basal, 2 apical and 3-4 ventral spines; apical spines of tarsomeres 2-4 of fore, mid and hind legs as follows: 1-22, 2-2-1, 1-1-1, basal spines absent; lengths of fore, mid and hind tarsomeres 266-117-85-64-69, 309-128-85-64-69, 395-192-128-75-85 $\mu \mathrm{m}(\mathrm{n}=7)$; fore, mid and hind tarsal ratios 2.1, 2.3, 2.0; claws paired, equal-sized, about 0.50 times as long as $5^{\text {th }}$ tarsomeres. Wing (Fig. 2) hyaline, dark spots as in female, costal ratio $0.73(\mathrm{n}=5)$. Terminalia (Fig. 13): $9^{\text {th }}$ sternum spiculate except on basal portion, posterior margin with a large, greatly convex median lobe bearing 4 long hairs; $9^{\text {th }}$ tergum tapering, with a slender and moderately pair of apicolateral processes. Gonocoxite twice as long as basal width; gonostylus nearly straight, 0.66 times as long as gonocoxite, moderately pilose basally. Aedeagus (Fig. 13) nearly triangular, basal arch extending to 0.37 of total length; lateral arms strongly sclerotized, nearly straight, ending in two pointed processes in distal portion, each with blunt apex. Parameres (Fig. 14) 0.94 times as long as aedeagus, broadly joined basally; stem curved in proximal portion; mid portion with a membranous, semicircular ventral lobe and a pointed process, externally directed, sometimes not so pointed due to assembly position; distal portion tapered to simple pointed apex, extending to 0.40 of the total length of paramere.

Distribution. Brazil (Rondônia and Pará).

Types. Holotype ơ, BRASIL, Rondônia: Rio Pacaás Novos, 08.IX.1999, N. Hamada \& U. Barbosa col., light trap. Allotype $₹$, BRASIL, Pará: Belém, Floresta da Área de Pesquisas Ecológicas do Guamá (APEG Forest), II. 1970, THG Aitken col., light trap.,

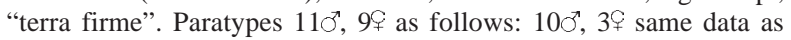
holotype; $4 \uparrow$ same data as allotype; $\sigma, 2 \subsetneq$ same data as allotype except VI.1970; VII. 1970, sticky trap. Holotype (Dip.Cer. 423), allotype (Dip.Cer. 424) and 10 paratypes (Dip.Cer. 425-434)

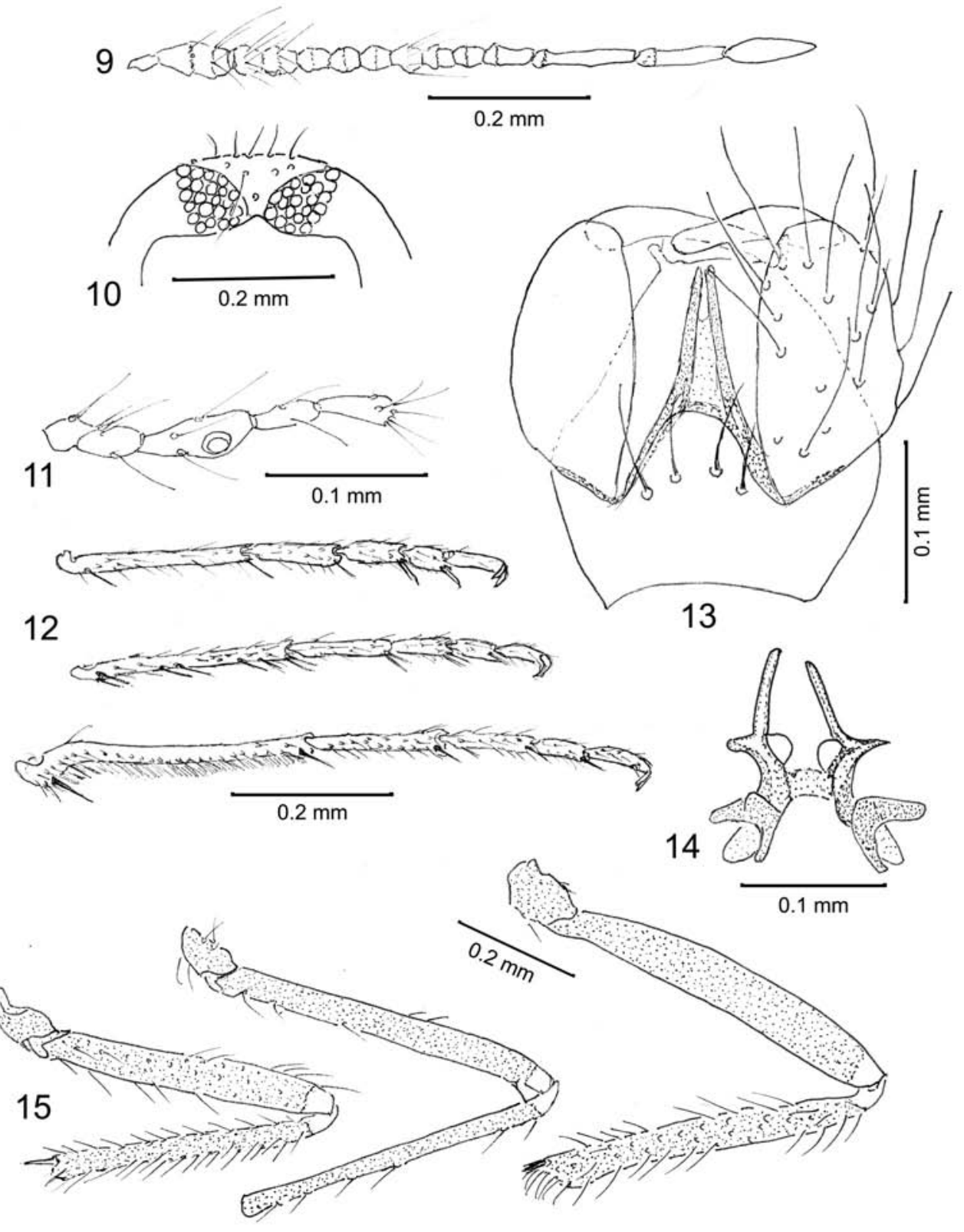

Figs. 9-15. Downeshelea oliveirai sp.nov., male: 9, antenna; 10, dorsal portion of head capsule, in anterior view; 11, palpus; 12, tarsi (top to botton) fore, mid and hind; 13, terminalia, parameres removed; 14, parameres; 15, legs (left to right) fore, mid and hind. 
deposited in Ceratopogonidae Collection of Instituto Oswaldo Cruz (IOC), Rio de Janeiro, Brazil; 10 paratypes: $4 \sigma^{*}, 2 \nsubseteq$ same data as holotype, deposited in Instituto Nacional de Pesquisas da Amazônia (INPA); $2 \%$ same data as holotype, $2 \subsetneq$ same data as allotype, deposited in Museu de La Plata, La Plata, Argentina $\left(\sigma^{\prime}, \mathcal{F}\right)$ and Faculdade de Saúde Pública, Universidade de São Paulo, São Paulo, Brazil $(\circlearrowleft, \uparrow)$.

Etymology. This species is named in honor to Dr. Sebastião José de Oliveira in recognition of his important contributions to the study of the Brazilian Chironomidae.

Discussion. D. oliveirai most closely resembles D. guianae by similar wing pattern and they can be easily separated by the shape of aedeagus and parameres. $D$. oliveirai has a triangular aedeagus, while in $D$. guianae it is nearly rectangular. Also, in D. oliveirai the parameres have a median lobe and a pointed process in mid portion, absent in $D$. guianae; the apex is long and tapered in $D$. oliveirai and with foot-shaped aspect in D. guianae.

Acknowledgements. To Dr. Neusa Hamada and Ulises Barbosa, Instituto Nacional de Pesquisa da Amazônia (INPA), Manaus, Brazil for sending us the collected specimens for analysis. To Rodrigo Mexas, for assistance in the wing photographs and plates of figures.

\section{REFERENCES}

Borkent, A. \& Spinelli, G. R. 2000. Catalog of the New World biting midges South of the United States of America (Diptera: Ceratopogonidae). Contributions on Entomology, International 4:1-107.

LANE, J. \& Wirth, W. W. 1964. The biting midge genus Monohelea Kieffer in the Neotropical Region (Diptera: Ceratopogonidae). Studia Entomologica 7:209-236.

MacAlpine, J. F.; Peterson, B. V.; Shewell, G. E.; Teskey, H. J.; Vockeroth, J. R. \& Wood, D. M. eds. 1981. Manual of Neartic Diptera. v.1. Monograph 27. Agriculture Canada. 674p.

Ratanaworabhan, N. C. \& Wirth, W. W. 1972. The biting midge genus Monohelea Kieffer in the Oriental Region (Diptera: Ceratopogonidae). Pacific Insects 14:439-473.

SzadzIEwsKI, R. 1996. Biting midges from Lower Cretaceous amber of Lebanon and Upper Cretaceous Siberian amber of Taimyr (Diptera: Ceratopogonidae). Studia Dipterologica 3:23-86.

Wirth, W. W. \& Grogan, JR. W. L. 1988. The predaceus midges of the World (Diptera: Ceratopogonidae, Tribe Ceratopogonini). Flora and Fauna Handbook n. 4, EJ Brill. $160 p$.

Wirth, W. W. \& Williams, R. W. 1964. New species and records of North American Monohelea (Diptera: Ceratopogonidae). Annals of the Entomological Society of America 57:302-310.

Recebido em abril de 2007. Aceito em abril de 2008. ISSN 0073-4721

Artigo disponível em: www.scielo.br/isz 